DOI: https://doi.org/10.32347/2077-3455.2020.56.66-72

UDC 721, 72.02

Olga Kysil

Postgraduate of Department of Information Technology in Architecture Kyiv National University of Construction and Architecture, Ukraine

solomyab@gmail.com

http://orcid.org/0000-0003-2873-6901

Nataliia Naichuk

Senior BIM Engineer/ Architect

"BIM Point", Krakow, Poland

n.naichuk@bimpoint.pl

http://orcid.org/0000-0002-9604-2197

\title{
DIGITAL REGISTRATION CARDS OF HBIM-BASED ARCHITECTURAL HERITAGE AS A NEW STAGE OF HISTORIC PRESERVATION OF KRAKOW (POLAND)
}

\begin{abstract}
A brief description of the status of the protection of architectural monuments in Poland in general and in Krakow, in particular, is provided. Describes a modern system of registration of monuments that are entered in the register of protection of historical heritage. The reasons and the relevance of the research in connection with the digitization of archival information and the filling of the Polish historical heritage portal have been proved. The purpose of the article is represented as a description of the research of creating a digital accounting card method. The results of the analysis of the existing White Card of the object we're given, which noted the amount of information that can be obtained automatically from the BIM model. The authors have refined the scheme of data collection workflow and registration of an architectural object, developed by the National Heritage Board of Poland. Some features of the information entry process are also outlined and further perspectives on improving the digital accounting card are described.

Key-words: HBIM; architectural heritage preservation in Krakow; Digital registration cards; certification of real estate; National Heritage Board of Poland.

Introduction. The development of the construction industry is much slower than in other industries. And the theories and techniques of protecting architectural monuments, restorations and renovations are less likely to change. And this is understandable because of the need for particularly careful work with such objects, noting their availability, status, environment, and architectural features. Poland has a large number of architectural monuments and Krakow is one of the leading cities to
\end{abstract}


work on this subject. The city paid attention to both the registration and the popularization of data on even small specimens of architecture (Fig. 1).

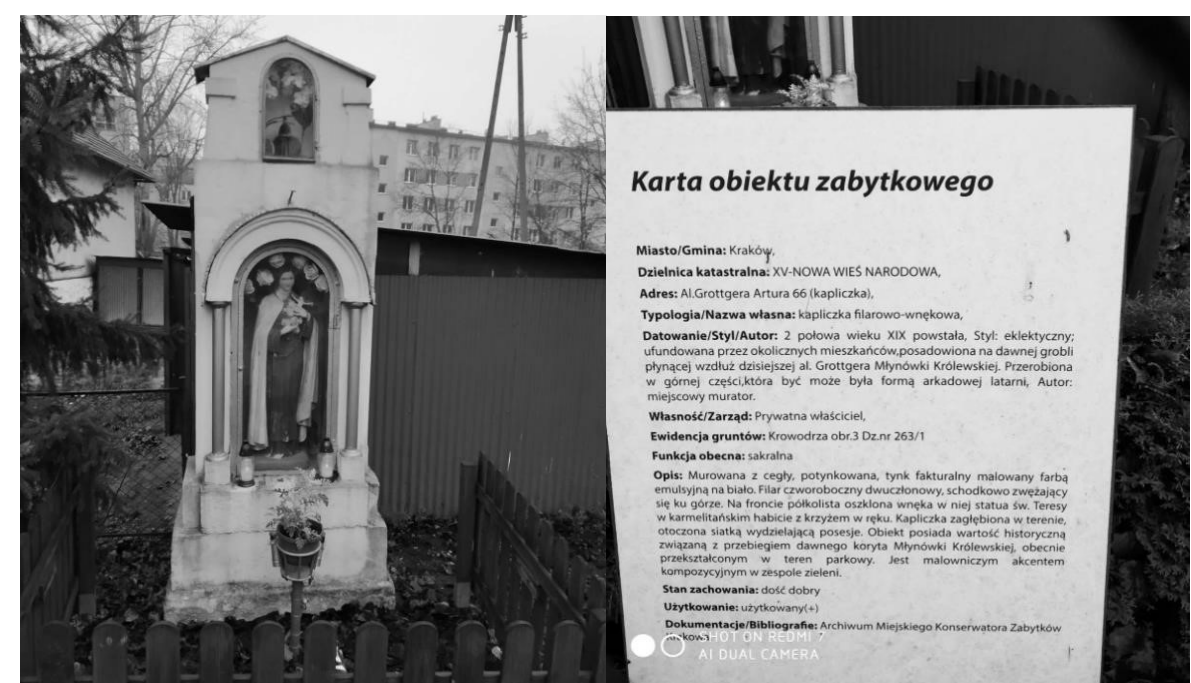

Fig. 1. Column-niche chapel and table with its centralized information (A. Grotger Street 66, Krakow), photo by authors.

According to the National Heritage Board of Poland, the history of the creation and modernization of registration cards of the country's historic architectural heritage has been around since 1958. But the modern registration system - the so-called White Card - was developed under the guidance of Prof. Wojciech Kalinowski in 1975. This card contains comprehensive information about the object.

Relevance of research. The development of new technologies through the digitization of project processes is happening in many countries in Europe and Asia, North America, Australia, and New Zealand. But the construction industry is not just new construction. Saving a large number of architectural monuments in Poland is challenging for IT professionals in architecture. Krakow is actively involved in digitizing archives and improving the registration of architectural historical heritage. An increasing number of objects are appearing on the https://zabytek.pl/ platform with the support of the National Heritage Board of Poland. Some of them have point clouds, 3D views, 2D drawings, historical description, photos, panoramic views from Google Street View. Therefore, a certain digital profile of the building is formed. But it should be noted that they have different degrees of development and information filling, not all data is stored in one place. Furthermore, filling in such a digital profile is done manually, often by different specialists, which leads to errors and inaccuracies. In many details, there is a lack of information.

According to the described work, this study proposes a method for obtaining a complete digital profile of an architectural monument by displaying it in a spreadsheet, by the White Card format adopted in Poland. Such a technique is based on processing and organizing pre-existing data in point clouds and archives, but takes 
the protection of the site to a new level of digitization and storage of information. Besides, it helps to plan restoration and repair work in a more sophisticated manner. Eventually, there are many tools in BIM technology to document the status of an object and manage its operation.

The purpose of the article is to describe and substantiate the study on the digitization of the process of registration of historical monuments of architecture using BIM technology, namely: automated filling of the registration card data with information obtained from the HBIM (Historical Building Information Modeling).

Main part. The so-called White Card consists of the main card (divided into 27 sections, which contains complete information about the object developed) and inserts for photos, drawings, and information that do not fit on the card. The recorded map is versatile, allowing to document objects of both individual and urban complexes, rural, architectural ensembles. It also documents various types of buildings, from shrines or small park buildings to large industrial plants or mines. In Poland, there is a single card template, which is important in the case of consistent, orderly record keeping in all restoration departments [3]. The plan for the study is to begin by harmonizing existing standards for landmark registration in Krakow with the method of creating HBIM models in the UK, as this country is the first to introduce state-of-the-art BIM technology and already has extensive experience in the field of designing new sites, and working with architectural heritage through information building technologies. Based on the information received, research and description of the methodology combining foreign experience and Polish standards for registration cards are made [2, 3, 4]. In the course of work, the Polish national glossary HBIM is being developed, which is extremely important for a common understanding of technology by all involved specialists and, as a result, successful implementation. The study is based on the HBIM model of the architectural monument in Krakow, based on the results of which proposing additional guidance on the existing National Heritage Board of Poland documents. The practical part of the research is to develop a spreadsheet template listing all the necessary items of information according to the existing guidelines for describing architectural monuments. The last stage of the practical study is to test the process automation. In this case, it is necessary to consider the possibility of saving files in IFC format for the convenience of opening in database systems of archives.

The study is based on the fact that the BIM model is itself a database that is replenished with information as the geometric volume is built. The dimensions of the building, if present, are taken from laser scanning, the point cloud. Photogrammetry, surveying, orthophotos and survey photos are also used.

According to this information, modeling is taking place. And further processing of materials is largely automatic in the model. For example, projections of 2D 
drawings are formed. Geodetic and orthophoto plan are also separate layers, they are worked on by relevant specialists and added to the federal, that is, the general model.

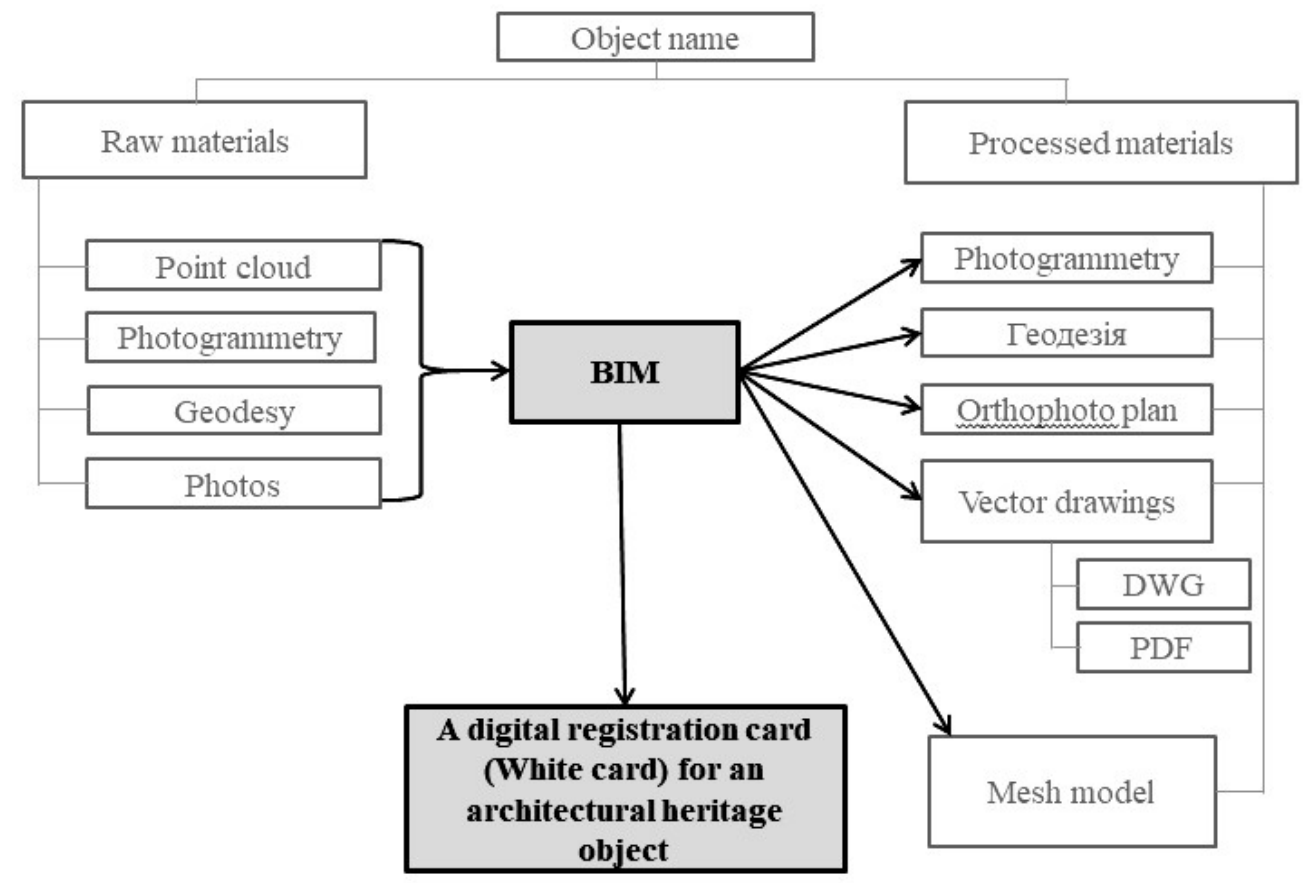

Fig. 2 Scheme of work on registration of an architectural object of historical heritage in accordance with the National Heritage Board of Poland instruction [2]

Such layers are also not only geometric surfaces but also a geoinformation model of the terrain. While building the geometry of an object based on a point cloud, it is possible to create a $3 \mathrm{D}$ mesh, which is the basis for quality visual presentation. (Fig. 2). In the analysis of the structure of the White Card [8, 9], two types of data were identified - which should be entered into the table manually and those which enter there automatically from the model. The "manual" at this stage include the data in columns: $1,2,7,8,9,10,12,20,21,22,23,24,26$. Thereby, the information on the graphs: $3,4,5,6,11,13,14,15,16,17,18,19,25$ can be obtained directly from the BIM model automatically. It should be noted that in the long run, it is likely that the owner and user of the heritage object will automatically receive the registry data, which should be described in columns 8.9. Also, memorial forms, registration numbers, and documents described in column 10 can also be automatically displayed in the table if they handle the appropriate link with the National Heritage Board of Poland portal www.nid.pl. Moreover, box 26 can also be filled in automatically in the case of editing and supplementing the card by the author of the BIM model. Box 19 can be classified as "automatic" if a restorer was present in the model creation process and monitored the provision of appropriate attributes with comments on the damaged elements of the object.

In the course of the research, a joint scheme of the work of the BIM modeler and the restorer is created, also the scope of responsibility of one or another specialist is 
determined. This is done on the basis of the project organization BIM standard and BEP (BIM execution plan) but adjusted for the HBIM project specifics.

Summary. The globalization of information sources is a general trend that affects the construction industry. Building information modeling as a database of architectural objects also provides tools for managing the life cycle of a building. This is extremely important for sites that require protection and monument restoration or reconstruction. Setting up quick systematic information from the model and automatically receiving a White card will greatly assist the National Heritage Board of Poland's work in updating the methods of registration and protection of heritage.

References:

1. Kysil O.V., Levchenko O.V., Mikhalchenko S.V. "Theoretical and methodological principles for the creation of a state database of building objects certified by the BIM technology", Web of Scholar, 6(24) RS Global, Warsaw 2018. DOI: https://doi.org/10.31435/rsglobal_wos/12062018/5761 (In Ukrainian)

2. National Heritage Board of Poland Good practices in the field of documentation of architectural monuments using modern methods of digital terrestrial recording, Warsaw, 2011. Electronic resource - Access mode:https://www.nid.pl/pl/Informacje_ogolne/Digitalizacja_zabytkow/ZALECENI A\%20DIGITALIZACYJNE/WYTYCZNE\%20dot\%20DOBRYCH\%20PRAKTYK logo_12012017KC.pdf (In Polish)

3. Ruzewich M. Records of architectural and construction monuments, Instruction, Conservation courier, Warsaw, 2008, p. 13-19. (In Polish)

4. National Heritage Board of Poland Instructions for developing the address card of a real estate monument (gez), Warsaw, 2008. Electronic resource - Access mode: https://www.nid.pl/pl/Dla_wlascicieli_i_zarzadcow/dla-samorzadow/gminnaewidencja-

zabytkow/Instrukcja_opracowywania_karty_adresowej_zabytku_nieruch.doc Polish)

5. Kysil O. BIM modeling of historical objects and tools for their conceptual analysis, Current issues in research, conservation and restoration of historic fortifications, The state school of higher education in Chelm, Lviv politechnic national university, Vol. 9, 2017, p.108-112

6. Kyivska K. Information Integrated Technologies for Building Object Modeling, Abstract for Candidate of Science Degree, KNUCA, Kyiv, 2016.

7. Sofia Antonopoulou BIM for heritage: developing a historic building information model, Historic England Guidance Document - Electronic resource Access mode: https://content.historicengland.org.uk/content/docs/guidance/bim-forheritage-consultation-draft.pdf (In English) 
8. National Heritage Board of Poland. Instructions for developing registration cards for real estate monuments entered in the register of monuments, Warsaw, 2011. Electronic resource Access mode: http://www.nid.pl/pl/Dla_specjalistow/Badania_i_dokumentacja/zabytkiruchome/instrukcje-wytycznezalecenia/Instrukcja\%20opracowywania $\% 20 \mathrm{kart} \% 20$ ewidencyjnych $\% 20$ zabytk\% $\% 3$ \%B3w\%20ruchomych\%20-\%20poprawione.doc (In Polish)

9. Registration card of real estate monuments entered in the register of monuments. Electronic resource - Access mode https://docplayer.pl/12095910-Kartaewidencyjna-zabytku-nieruchomego-wpisanego-do-rejestru-zabytkow.html (In Polish)

10. National Heritage Board of Poland Report on the state of preservation of real estate monuments in Poland. Monuments entered in the register of monuments (registers Vol. A and C) Electronic resource - Access mode: https://nid.pl/pl/Wydawnictwa/inne\%20wydawnictwa/RAPORT\%200\%20STANIE \%20ZACHOWANIA\%20ZABYTK\%C3\%93W\%20NIERUCHOMYCH.pdf Polish)

11. Annex to Resolution No. XXXIII / 487/17 of the Malopolska Voivodship Assembly of February 27, 2017. Report on the implementation in 2014-2015 of the Provincial Program for the Protection of Monuments in Malopolska for the Years 2014-2017. Electronic resource Access mode: https://www.malopolska.pl/_userfiles/uploads/kultura\%20i\%20dziedzictwo/Zabytki/z a $\%$ C5\%82.\%20do\%20uchwa\%C5\%82y\%20SWM\%20XXXIII $487 \quad 17 \% 20$ \%20sprawozdanie\%20z\%20WPONZ\%202014-2015.pdf (In Polish)

12. Kozlova T., Talapov V. (2010), "On the technique of BIM application in modeling of architectural monuments", [online] AMIT, 3 (12) Available: https://docplayer.ru/45661621-O-metodike-primeneniya-bim-v-modelirovaniipamyatnikov-arhitektury-about-methods-of-using-bim-in-modeling-of-architecturalmonuments.html [Accessed August 25, 2019] (In Russian)

13. Kozlova T., Talapov V. (2009), "Experience of information modeling of architectural monuments", [online] AMIT, 3(8) Available: https://docplayer.ru/51557731-Opyt-informacionnogo-modelirovaniya-pamyatnikovarhitektury-t-i-kozlova-v-v-talapov.html [Accessed August 25, 2019]. (In Russian)

14. Oreni D., Brumana R., Georgopoulos A. and Cuca B. (2013), «HBIM for conservation and management of built heritage: towards a library of vaults and wooden bean floors», ISPRS Annals of the Photogrammetry, Remote Sensing and Spatial Information Sciences, Volume II-5/W1, XXIV International CIPA Symposium, 2 - 6 September 2013, Strasbourg, France. (In English) 
15. Historic England, (2017), «BIM for Heritage: Developing a Historic Building Information», Model. Swindon. Historic England. Available: https://historicengland.org.uk/advice/technical-advice/recording-heritage/ [Accessed August 25, 2019] (In English)

16. Murphy M. (2012), «Historic Building Information Modelling (HBIM) For Recording and Documenting Classical Architecture in Dublin 1700 to 1830», Dublin. (In English)

17. Megahed N.A. (2015), «Towards a theoretical framework for HBIM approach in historic preservation and management», Archnet-IJAR, Volume 9, Issue 3, pp.130147. (In English)

18. Stefano Della Torre (2016), «Perspectives on Historic BIM Developments in Italy» [online] AECbytes Viewpoint \#82 (December 15, 2016). Available: http://www.aecbytes.com/viewpoint/2016/issue 82.html [Accessed August 25, 2019]. (In English)

19. Talapov V.V. (2015), "BIM technology and its connecting role for different architecture epochs", Balandinsky readings, 10(2), pp.325-328. (In Russian)

\section{Анотація}

Кисіль Ольга Валентинівна, аспірант кафедри інформаційних технологій в архітектурі, Київського національного університету будівництва i архітектури; Найчук Наталія Мирославівна, ВIM менеджер, архітектор "BIM Point".

Цифрові ресстраційні картки пам'яток архітектури на основі НВІМ моделей як новий щабель збереження історичного спадку Кракова (Польща).

Надана коротка характеристика стану охорони архітектурних історичних пам'яток у Польщі і в Кракові зокрема. Описано сучасну систему реєстрації пам'яток, що вписані в реєстр охорони історичної спадщини. Доведено підстави та актуальність дослідження у зв'язку з діджиталізацією архівної інформації та наповненням порталу історичної спадщини Польщі. Означено мету статті як опис дослідження методики створення цифрової картки обліку. Надані результати аналізу існуючої Білої картки об'єкту, де зауважено об'єм інформації, який можна отримати автоматично 3 BIM моделі. Авторами доопрацьовано схему роботи зі збору даних та реєстрації архітектурного об'єкту, розроблену National Heritage Board of Poland. Також описані деякі особливості процесу внесення інформації та окреслено подальші перспективи вдосконалення цифрової картки обліку.

Ключові слова: НВIM; збереження архітектурного спадку Кракова; цифрові реєстраційні картки; паспортизація об'єктів нерухомості; Національний Інститут Спадщини Польщі. 